\title{
Analysis and Suggestion on Joint Operation of the Green Trading Systems in China
}

\author{
Jian Jiao \\ College of Economics and Management \\ China Three Gorges University \\ Yichang, China \\ jianjiao@126.com
}

\begin{abstract}
China's domestic carbon trading market was launched in December 2017. This is a major measure taken by China to tackle climate change and achieve the goal of energy conservation and emission reduction. Besides the domestic carbon emissions trading market, there are several other marketoriented trading systems such as the trading of energy-use rights, the trading of energy-saving and green power certificate trading in China. These trading systems guide China's economy towards a green and sustainable development from different starting points and market rules. The development of these trading systems, trading coverage areas, trading rules, and other circumstances is analyzed. The problems faced by several green trading systems are put forward. Suggestions on the follow-up of the domestic carbon emission trading market and other trading systems are given.
\end{abstract}

Keywords-Carbon market; Carbon emission; Green trade; Joint operation

\section{INTRODUCTION}

Following the pilot carbon emission trading market of 7 provinces and cities in China in 2013, the domestic carbon emission trading system was launched in December 2017. This is an essential measure for China to implement the market-oriented approach to control the total greenhouse gas emissions and achieve green and sustainable development. Energy conservation and emission reduction are a complex system project, and the launch of the domestic carbon emission trading market is one of the most important parts of China's efforts to tackle climate change. Besides domestic carbon trading market, a number of green trading systems related to emission reduction are also being implemented in parallel. In these trading systems, the trading of energy-use rights, the trading of energy saved and the trading of the green certificate are the most influential. These trading systems may influence or intersect each other, but these different trading systems are liable to be linked in the future. How to coordinate these trading systems so that they promote each other rather than restrict each other is an unsolved problem.

\section{ANALYSIS OF THE MAIN ENERGY-SAVING AND EMISSION REDUCTION MARKET IN CHINA}

\section{A. Domestic Carbon Emission Trading System}

The carbon emissions trading market often referred to as the carbon market for short, refers to the carbon dioxide which is the largest content in greenhouse gas. Trading in carbon markets is the right to emit greenhouse gas. In the deal, the government set the total amount of greenhouse gas allowed to be emitted, and set the initial emission, or quota, for the trading body. For a certain period of time (usually one year), the emissions of the trading entity within the quota are not required to pay an additional fee for the emissions. And the remaining quota can be traded for a profit. If the amount of carbon dioxide a company emits exceeds its quota, it will have to be paid for the excess. The trading system will help to achieve low-cost emission reduction targets by mobilizing the initiative of business owners to reduce emissions, attracting investment and encouraging international cooperation [1].

China's initial participation in the carbon emissions trading scheme began with the implementation of the Clean Development Mechanism (CDM) international project proposed in the Kyoto protocol in 2002. Since 2013, China's CDM project has gradually withdrawn from the global trading market, and China's carbon trading has shifted from the international market to the domestic market. From June 2013 to June 2014, China launched pilot carbon emission trading markets in Beijing, Tianjin, Shanghai, Chongqing, Hubei, Guangdong, and Shenzhen. In January 2015, the interim measures on the management of carbon emission trading, which is applicable to the construction of the domestic carbon market, came into effect [2].

In January 2016, the national development and reform commission of China issued the notice on the implementation of the key work of the domestic carbon emission trading market, which proposed that the domestic carbon market would cover eight industries including petrochemical, chemical, building materials, steel, non-ferrous metals, papermaking, electric power, and aviation at the initial stage of operation. However, the domestic carbon market is harder to launch than previously thought. China's national development and reform commission issued the document "domestic carbon emission trading market construction plan (power generation industry)" On December 19, 2017. The document noted that the construction of China's carbon market would take the power generation industry as the breakthrough point. It is expected to allocate carbon emission quota to power generation enterprises in 2018 and calculate the quota will issue in 2019. 


\section{B. The Trading of Energy-Use Rights}

The term energy-use rights refers to the right granted to an energy-using unit to use a certain amount of all kinds of energy in one year. The rules for the trading of energy-use rights are similar to those for carbon emissions trading. When implementing the trading of energy-use rights, the initial energy quota of the enterprise will be established under the fixed total energy consumption. In a given year, companies that exceed quotas pay an additional economic cost, and those that have a surplus can sell for a profit [3].

The proposal of the right to utilize energy originates from the government's control of energy consumption, which is upgraded from a single control of energy intensity to a comprehensive control of total energy consumption and energy intensity. In 2007, China's 11th five-year plan for energy development began to set the dual targets of reducing energy consumption and energy intensity. In 2013 and 2016, the Chinese government issued the 12th five-year plan for energy development and the 13th five-year plan for energy development respectively, and also set corresponding targets for reducing energy consumption and energy intensity. It can be seen from China's existing practice that the task of controlling total energy consumption is more difficult than reducing energy intensity.

Most of China's carbon emissions come from burning fossil fuel, with 68 percent coming from burning coal. It believes that China's energy-saving contributes more than $80 \%$ of carbon emission reduction, which determines that there is a high overlap between energy-use rights and carbon emission rights. However, the trading of energy-use rights and the carbon emissions trading are irreplaceable. The purpose of the trading of energy-use rights is to optimize the energy structure, improve energy efficiency and control the total energy consumption. Carbon emissions trading focuses on end management, aiming to reduce greenhouse gas emissions and control the concentration of greenhouse gas in the atmosphere.

The two trading systems apply to different industries. The domestic carbon emission trading market was only included in the power generation industry at the initial stage of operation, while the trial of the trading of energy-use rights is not confined to the industry at present, and its coverage is much wider.

\section{The Trading of Energy-Saving}

Energy-saving refers to the reduction in energy consumption when the same needs are met or the same goals are achieved. Energy-saving is a reference index to measure the energy-saving effect of a company. It does not judge the total energy consumption but needs to calculate the difference between the actual energy consumption and the comparison benchmark. Energy-saving trading is the market behavior of a company to trade energy-saving.

During China's 11th five-year plan period (2006-2010), governments at all levels set binding energy-saving targets for key energy-using enterprises within their jurisdiction as the main quantitative indicators to assess their energy-saving effects. At this stage, energy-saving and emission reduction are mainly achieved through administrative management.
Unlike the trading of energy-use rights, there is no pilot the trading energy-saving at the national level, nor is there a clear timetable for implementing the national energy-saving trading. In the process of the energy-saving transaction, the measurement, calculation, and verification of energy-saving is a complex and highly technical work, which is easily controversial [4]. The trading of energy-use rights is more concise and clear, and it is easier to connect with carbon trading by adhering to the total control target. The trading of energy-saving is the primary form of the trading of energy-use rights. The trading of energy-use rights is likely to replace the trading of energy-saving in the future [5].

\section{Green Certificate Trading}

The green certificate is an electronic certification issued by the national renewable energy information management center of China for the online electricity generated by onshore wind farms or photovoltaic centralized power stations. On July 1, 2017, China launched the green certificate voluntary subscription and established the green certificate system. Power generation enterprises that receive green certificates can sell green certificates on the countrywide green certificate voluntary subscription platform. This lays the foundation for the implementation of renewable energy power quota assessment and the mandatory binding trading of green certificates in the future [6].

In the voluntary purchase phase of green certification, green certification is mainly to solve the problem of subsidy source of wind power and photovoltaic power generation. Depending on the current regulations, the main source of subsidies for renewable energy in China is the surcharge on electricity prices of renewable energy. In recent years, China's wind power and photovoltaic power generation have developed rapidly. The surcharge imposed by the state is not sufficient to cover the subsidy costs, and it is very difficult to add the surcharge. The introduction of green certificates is a supplement to the surcharge on electricity tariffs for renewable energy. However, green certification is more significant as a supporting policy tool for China's renewable energy quota system. The medium - and long-term development plan for renewable energy released by China in September 2007 proposed that the proportion of non-fossil energy consumption in China should reach $15 \%$ by 2020 . The Sino-Us joint statement on climate change released by China in November 2014 proposed that non-fossil energy accounts for about $20 \%$ of primary energy consumption in China by 2030. In order to attain the above goals, it is imperative to implement the renewable energy quota system.

The renewable energy quota system is a mandatory regulation on the market share of renewable energy power generation. Power generation enterprise completes the renewable energy quota by establishing the renewable energy generation project or by purchasing the green certificate. Green certificates accurately measure carbon dioxide emissions and have a natural connection to the carbon trading market. The green certificate aims to reduce emissions by changing the energy mix and increasing the proportion of renewable energy in energy consumption. 


\section{PROBlems IN THE OPERATION OF MULTIPLE TRADING} SYSTEMS

\section{A. Lack of Coordination Mechanism Between Different Transactions}

For provinces and municipalities that simultaneously implement the trading of energy-use rights, the trading of energy-saving and carbon emissions trading, an enterprise may have to participate in multiple transactions at the same time, and there may be repeated transactions of the same product. The trading of energy-use rights, the trading of energy-saving and carbon emissions trading have a high degree of coincidence and similarity. Improper handling will bring the heavy burden to enterprises, resulting in the waste of public resources. There is not any clear plan on how to link multiple transactions, and the lack of coordination mechanism increases market uncertainty.

Take Fujian province as an example: in 2017, the target of the trading of energy-use rights pilot project is the enterprise whose annual comprehensive energy consumption reaches 5,000 tons of standard coal and above in the two industries of thermal power generation and cement manufacturing within its administrative region. For the trading of energy-saving, the principal trading body is the enterprises that consume 5,000 tons of standard coal and above annually in Fujian province. In December 2017, the trading subject of the domestic carbon emission rights trading market determined by the national development and reform commission is: enterprises or other economic organizations whose annual emissions in the power generation industry reach 26,000 tons of carbon dioxide equivalent (the comprehensive energy consumption is about 10,000 tons of standard coal) and above. In Fujian province, transaction subjects of energy rights, energy-saving and carbon market all include power generation industry. It is possible that the same project can be traded in both energysaving and carbon market. How to avoid duplicating the transaction and to connect and transform different types of the transaction is a practical problem to be solved.

\section{B. The Connection Between Green Certificate and Carbon Market Is Not Clear}

The carbon Emission trading market has two types of basic products, one is the Emission Reduction (i.e., quota) initially allocated by the policymakers to enterprises, and the other is the carbon offset generated by carbon Emission Reduction projects, known as the Chinese Certified Emission Reduction (CCER).

In June 2012, the national development and reform commission of China issued the interim measures on the management of voluntary greenhouse gas emission reduction trading, which provided the rules for the filing, development and management of China's voluntary greenhouse gas emission reduction projects. Carbon offset from these emissions reduction projects is the CCER.

CCER is a flexible and low-cost mechanism by which authorities allow companies to meet their carbon emission reduction obligations beyond emission limits.
At present, the relationship between green certificate and CCER system is not well defined. At the beginning of the domestic carbon market, green certificate system has not yet been mandatory trading and its trading is entirely voluntary. At this time, the application for the new CCER project was suspended, and the enterprise completed the carbon emission performance only in the form of quota but not in the form of CCER. At this point, undefined parts of the green certificate and CCER system have not yet caused substantial economic or policy implementation problems for enterprises.

When the CCER of the domestic carbon market and the mandatory trading system of green certificates are implemented simultaneously, the collision between the two is inevitable. If the power generation company sells the electricity generated from renewable energy as a green certificate, the unit that buys the green certificate will get the corresponding emission reduction. However, when the same renewable energy power generation project is involved in carbon market trading at CCER, the problem of repeated calculation of emission reduction of the same product arises.

\section{SUGGESTIONS ON PARALLEL DEVELOPMENT OF CHINA'S CARBON MARKET AND OTHER TRADING SYSTEMS}

\section{A. Each Trading Market Can Operate Relatively Independently at the Initial Stage of Domestic Carbon Market Operation}

For the government, smooth operation of the carbon market is the key issue to be considered. During the pilot operation of the carbon market, in order to ensure the market is not impacted, the maximum amount of CCER products allowed to participate in each pilot market is set at 5\% to $10 \%$. Also aimed at ensuring the smooth operation of the domestic carbon market, the national development and reform commission suspended the acceptance of new CCER-related business in March 2017. At the beginning of the domestic carbon market, carbon quota is the only transaction object. It can be understandable that after the reopening of the registration, the access conditions of CCER will be more stringent. The above arrangement shows the cautious attitude of government departments in the operation of the domestic carbon market.

In order to avoid the problems caused by the crossoperation of different trading systems, all kinds of trading can be kept relatively independent in the preliminary operation of the domestic carbon market. One approach is to stagger the trading time of different trades. For example, only after the completion of the annual implementation of carbon emission rights, enterprises can enter other markets. A more complete separation would be to limit the trading body's participation in only one trading system, avoiding a transaction crossover at its source. For example, at present, the participants in the domestic carbon market are energy-use units capable of reaching 10,000 tons of standard coal and above per year. To avoid cross-trading, the participants in the trading of energysaving or energy-use rights can be set as energy-use units below 10,000 tons of standard coal per year. 


\section{B. Learn from the Practical Experience Gained in the Pilot Carbon Market}

Since the progress of China's pilot carbon market in 2013, trading parties have accumulated rich resources and experience. The above practical experience can be used for reference in relevant regions before the regulation of the linkage between China's carbon market and energy-use rights and energy-saving trading has been issued. The development of the trading of energy-use rights and energy-saving can fully learn and make use of the management experience of the carbon market, quota allocation method, reporting platform, trading system, third-party verification institutions and other resources to realize fewer detours and rapid development.

In the pilot project of carbon emission trading, the carbon market in Shanghai and Beijing explored the relationship between the carbon market and energy-saving trading. In the plan released by Shanghai in November 2013, the audited energy-saving of pilot enterprises was converted into carbon emission reduction according to the ratio of 2.23 tons of carbon dioxide to 1 ton of standard coal. In September 2014, Beijing launched a plan to incorporate energy-savings into carbon offsetting projects. The carbon emission reduction of energy-saving projects is estimated according to the actual carbon emission reduction generated during the continuous and stable operation of energy-saving projects for one year, and is converted into carbon emission reduction through corresponding conversion coefficient. Previous successful practices can be learned before the relevance of the existing trading system is clear.

\section{Apply the Resources and Experience Accumulated in the Management of Key Energy Units}

Since the 11th five-year plan period (2006-2010), the Chinese government has paid great attention to energy conservation and emission reduction. From the "energy conservation action of thousands of enterprises" in the 11 th five-year plan to the "energy conservation and low-carbon action of thousands of enterprises" in the 12th five-year plan (2011-2015), government departments have accumulated valuable experience in the management of key energy-use units. The Chinese government has established a set of relatively intact management measures, such as energy metering and monitoring infrastructure construction, energy utilization status report and energy audit. These achievements and experience can be fully utilized in the trading of energyuse rights. When enterprises face different trading systems, mature management methods can decrease the burden on enterprises and improve their acceptance of the trading of energy-use rights.

\section{Determine the Transaction Boundary Between CCER and Green Certificate}

Compared with the carbon trading market, the green certificate market is more flexible. It cannot only examine the renewable energy quota of power generation enterprises, but also examine the green power sales of power selling enterprises. Therefore, it can be more thoroughly marketized and more operable. The main purpose of green certification is to provide a way for power generation enterprises to achieve the proportion of renewable energy power. If the green certificate cannot become one of the implementation methods in the carbon market in the future, then the carbon emission reduction corresponding to the green certificate cannot be recognized in the carbon market, so the willingness of nonpower generation control and emission control enterprises to buy the green certificate will be limited. If the green certificate becomes a performance method for enterprises in the carbon market, the trading boundary between CCER and green certificate should be clarified, and the mutual exclusion between CCER and green certificate should be clearly defined, so as to solve the problem of repeated calculation of carbon emission reduction. For the same project, the enterprise can only choose the green certificate or CCER for development. At that time, the enterprise will judge according to the price level and choose the product with higher profit to develop.

\section{CONCLUSION}

In the process of China's construction of ecological civilization, the establishment of a domestic carbon market is an inevitable choice for promoting green transformation and development. A number of green trading systems running simultaneously with the domestic carbon market are all promoting energy conservation and emission reduction in a market-oriented manner but from different perspectives. These trading systems are likely to be meaningful from the point of departure of individual policymaking and their individual results. In general terms, these policy tools are all in the same direction, but more discussion is needed on whether they are effective overall and whether they can achieve their objectives.

\section{REFERENCES}

[1] S. Perdan and A. Azapagic, "Carbon trading: Current schemes and future developments," Energy policy, vol. 39, pp. 6040-6054, 2011

[2] D. Zhang, V. J. Karplus, C. Cassisa, and X. Zhang, "Emissions trading in China: Progress and prospects," Energy policy, vol. 75, pp. 9-16, 2014.

[3] N. Li, M. Shi, Z. Shang, and Y. Yuan, "Impacts of total energy consumption control and energy quota allocation on China's regional economy based on a 30-region computable general equilibrium analysis," Chinese geographical science, vol. 25, pp. 657-671, 2015.

[4] X. Zhao, H. Li, L. Wu, and Y. Qi, "Implementation of energy-saving policies in China: How local governments assisted industrial enterprises in achieving energy-saving targets," Energy Policy, vol. 66, pp. 170-184, 2014.

[5] Q. Wang and X. Chen, "Energy policies for managing China's carbon emission," Renewable and Sustainable Energy Reviews, vol. 50, pp. 470-479, 2015.

[6] Q. Weng and H. Xu, "A review of China's carbon trading market," Renewable and Sustainable Energy Reviews, vol. 91, pp. 613-619, 2018. 